\title{
Parkinson's Disease: Potential Actions of Lithium by Targeting the WNT/ $\beta$-Catenin Pathway, Oxidative Stress, Inflammation and Glutamatergic Pathway
}

\author{
Alexandre Vallée ${ }^{1, *} \mathbb{D}$, Jean-Noël Vallée ${ }^{2,3}$ and Yves Lecarpentier ${ }^{4}$ \\ 1 Department of Clinical Research and Innovation (DRCI), Hôpital Foch, 92150 Suresnes, France \\ 2 Centre Hospitalier Universitaire (CHU) Amiens Picardie, Université Picardie Jules Verne (UPJV), \\ 80054 Amiens, France; valleejn@gmail.com \\ 3 Laboratoire de Mathématiques et Applications (LMA), UMR CNRS 7348, Université de Poitiers, \\ 86021 Poitiers, France \\ 4 Centre de Recherche Clinique, Grand Hôpital de l'Est Francilien (GHEF), 6-8 rue Saint-Fiacre, \\ 77100 Meaux, France; yves.c.lecarpentier@gmail.com \\ * Correspondence: alexandre.g.vallee@gmail.com; Tel.: +33-146-257-352
}

Citation: Vallée, A.; Vallée, J.-N.; Lecarpentier, Y. Parkinson's Disease: Potential Actions of Lithium by Targeting the WNT/ $\beta$-Catenin Pathway, Oxidative Stress, Inflammation and Glutamatergic Pathway. Cells 2021, 10, 230. https:/ doi.org/10.3390/cells10020230

Academic Editors: Pyotr A. Slominsky and Maria Shadrina Received: 25 November 2020

Accepted: 8 January 2021

Published: 25 January 2021

Publisher's Note: MDPI stays neutral with regard to jurisdictional claims in published maps and institutional affiliations.

Copyright: (c) 2021 by the authors. Licensee MDPI, Basel, Switzerland. This article is an open access article distributed under the terms and conditions of the Creative Commons Attribution (CC BY) license (https:/ / creativecommons.org/licenses/by/ $4.0 /)$.

\begin{abstract}
Parkinson's disease (PD) is one of the major neurodegenerative diseases (ND) which presents a progressive neurodegeneration characterized by loss of dopamine in the substantia nigra pars compacta. It is well known that oxidative stress, inflammation and glutamatergic pathway play key roles in the development of PD. However, therapies remain uncertain and research for new treatment is mandatory. This review focuses on the potential effects of lithium, as a potential therapeutic strategy, on PD and some of the presumed mechanisms by which lithium provides its benefit properties. Lithium medication downregulates GSK-3beta, the main inhibitor of the WNT/ $\beta$ catenin pathway. The stimulation of the WNT/ $\beta$-catenin could be associated with the control of oxidative stress, inflammation, and glutamatergic pathway. Future prospective clinical trials could focus on lithium and its different and multiple interactions in PD.
\end{abstract}

Keywords: WNT/beta-catenin pathway; lithium; Parkinson; inflammation; oxidative stress; glutamatergic pathway

\section{Introduction}

Parkinson's disease (PD) is one of the major neurodegenerative diseases (ND) with progressive neurodegeneration characterized by loss of dopamine in the substantia nigra pars compacta. PD originates in the brainstem or spinal cord of patients and PD remains asymptomatic for a very long time [1,2]. The aetiologies of PD are still unknown, but the presence of Lewy bodies (clusters of $\alpha$-synuclein and ubiquitin proteins in neurons) has been observed from the early stages of the disease. PD presents symptoms of tremor, stiffness, bradykinesia, and postural instability. These symptoms only appear when most of the dopaminergic (DAergic) cells are lost in the substantia nigra pars compacta, expressing smooth and coordinated regulation of striatal motor circuits also lost [3]. Depression or Sleep behavior disorders with rapid eye movements (REM) are non-motor symptoms that can precede the onset of the disease. Aging is one of the main risk factors for neurodegeneration. Aging can deregulate the various pathways that control cellular homeostatic phenomena. Altered cells are the sites of many molecular abnormalities [4]. Several metabolic mechanisms, such as inflammation and oxidative stress, can lead to a neurodegenerative process. PD shows metabolic remodeling resulting in concomitant increase in oxidative stress and neuroinflammation $[5,6]$. In recent years, the $W N T / \beta$-catenin pathway has been considered one of the main pathway involved in PD $[7,8]$. The deregulation of the WNT pathway is considered as an initiating event of the PD [9]. 
Lithium, which was introduced in 1949 , is the primary drug commonly used for the treatment of chronic mental illnesses, such as bipolar disorder, characterized by depressive and manic cycles. Several studies have shown that prophylactic lithium can reduce manic relapses, although its effectiveness was significantly lower in reducing depressive relapses [10]. Moreover, other studies have shown that lithium therapy may reduce suicides and suicide attempts in patients with mood disorders [11]. Recent advances seem to show that the benefits of lithium go beyond just treating mood. Neuroprotection against excitotoxicity or brain damage is another role of lithium [12]. However, on the other hand, several reports have shown that a high dose of lithium can induce irreversible neurotoxicity effects [13]. Clinical manifestations of lithium toxicity include renal dysfunction, neurologic dysfunction, gastrointestinal upset, cardiac manifestations and endocrine abnormalities [14]. Nevertheless, the ability of lithium to cause chronic kidney disease appears to be very low [15]. Lithium poisoning has a low mortality rate and persistent cerebellar neurological deficits are uncommon in uncomplicated acute poisoning [16]. Same observations were reported for appropriate lithium doses with rare cardiac manifestations [17], gastrointestinal upset [18] and endocrine manifestations [19]. Moreover, low doses of lithium are correlated with lower side-effects [20] and two reviews advocate the use of lithium therapy despite its potential side effects [21,22]. This review focuses on the potential effects of lithium, as a potential therapeutic strategy, on PD and some of the metabolic mechanisms, oxidative stress, and inflammation, by which lithium provides its beneficial properties.

\section{Parkinson's Disease and Oxidative Stress}

Numerous studies have shown an increase in oxidative stress (OS) in the emergence of PD [23-29]. PD is characterized by mitochondrial dysregulation as evidenced by increased production and subsequent release of reactive oxygen species (ROS) [30]. Decreased mitochondrial activity leads to cell damage and death by decreased energy production due to improved OS [31]. OS and mitochondrial deregulation are associated with dementia and cell death [32-34]. The development of PD is characterized by an improvement of these operating systems [5]. Decreased respiratory chain activity in PD substance nigra pars compacta is associated with increased ROS production and apoptosis $[30,35,36]$.

As part of oxidative metabolism, oxygen free radicals can be physiologically produced by the human body. Within each mitochondria, during aerobic respiration, molecular oxygen $\left(\mathrm{O}_{2}\right)$ is reduced to water molecules. By this phenomenon, $\mathrm{O}_{2}, \mathrm{H}_{2} \mathrm{O}_{2}$ and $\mathrm{OH}$ are produced by an oxygen leakage [6]. During infections, phagocytic cells are caused to generate high levels of $\mathrm{NO}, \mathrm{O}_{2}$ and $\mathrm{H}_{2} \mathrm{O}_{2}$ to defend the organism to reduce infection. However, the free radicals produced can also destroy healthy cells in the body and can have a detrimental effect [37].

Many enzymes, including tyrosine hydroxylase, L-amino acid oxidase, and monoamine oxidase (MAO) are involved in dopamine metabolism and in the production of ROS [38]. The production of ROS is found to be exacerbated during inflammation. However, many signals can be confused with ROS. In microglia, the aggregation and accumulation of ROS-induced proteins may be the cause of the inflammation observed [39]. OS and inflammation are associated with four improved mechanisms in PD: reduction in $26 \mathrm{~S}$ proteasomal activity, increase in iron levels, decrease in glutathione (GSH) levels, and impaired regulation of the mitochondrial complex I $[40,41]$. In the physiological stage, MAO produces $\mathrm{H}_{2} \mathrm{O}_{2}$. Conversely, during $\mathrm{PD}, \mathrm{H}_{2} \mathrm{O}_{2}$ is transformed into hydroxyl radicals $(\mathrm{OH})$ by iron via Fenton reactions. Thus, $\mathrm{H}_{2} \mathrm{O}_{2}$ and $\mathrm{OH}$ improve the operating system [42]. $\mathrm{H}_{2} \mathrm{O}_{2}$ and $\mathrm{OH}$ oxidize GSH in the cytosol [43] causing GSH leakage into PD. The release of GSH molecules leads to the conversion of glutamate and cysteine into glutamyl peptides and cysteinyl peptides. These produced peptides appear to be toxic to dopaminergic cells by increasing ROS production and binding to the cell membrane in dopaminergic neurons. These peptides decrease the activity of complex I of the mitochondria leading to the production of ROS and to OS [44]. Dopaminergic (DAergic) cells are unable to repair misfiled proteins in PD due to damaged seen in proteasomal systems [45]. OS stimulates the carbonylation of 
proteins, an irreversible and irreparable process. Carbonylation is a phenotype of cellular senescence leading to the aggregation of proteins. In PD, the aggregation of these proteins is one of the main pathological phenomena of nigrostriatal DAergic neurons. Thus, these aggregated proteins are at the origin of neuroinflammation and OS [46].

\section{Parkinson's Disease and Inflammation}

Some evidence has shown that inflammation plays a major role in PD [47]. Inflammation can activate apoptosis pathways in dopamine cells in PD [48,49]. The interaction between PD and inflammation is mutual. Inflammation leads to the death of dopaminergic cells but on the other hand, the death of DAergic cells leads, in a vicious feedback, to inflammation [50]. Additionally, inflammation causes OS, forcing DAergic cells to activate their death signals [51]. Multiple inflammatory factors, including microglia, play a major role in the development of PD [52]. Activation of microglia stimulates their pro-inflammatory enzymes (such as inducible nitric oxide synthase and cyclooxygenase) and the release of pro-inflammatory cytokines (such as CXC motif chemokine 12 ligand (CXCL12), tumor necrosis $\alpha$ (TNF- $\alpha)$, interferon- $\gamma($ IFN- $\gamma$ ), interleukin (IL)-6 and IL-1 $\beta$ [53]. The NF- $\kappa$ B pathway has an important role in the secretion of these pro-inflammatory enzymes and cytokines within the microglia [54]. TNF- $\alpha$ activates the process of apoptosis by the death domain of the TNF-R1 receptor stimulating caspases 1 and 3 [55]. TNF- $\alpha$ causes a decrease in $c-R e l-N F-\kappa B$. c-Rel-NF- $\kappa$ B possesses neuroprotective action by inhibiting apoptosis through B-cell lymphoma-extra-large pathway within dopaminergic neurons [54]. High levels of expression of CXCR4 (referred to fusin) and its CXCL12 ligand have been shown in PD. The complex formed by CXCR4-CXCL12 activates caspase 3, which is the cause of apoptosis leading to the death of neural cells $[56,57]$. The IFN- $\gamma$-IFNGR signaling complex phosphorylates the leucine-rich repeat protein kinase 2 (LRRK2) [58]. In microglia and dopaminergic neurons, LRRK2 binds with many cellular signaling. The activated LRRK2 protein inhibits the expression of $c-R e l-N F-\kappa B$. Thus, inflammation is increased by insufficient c-Rel-NF- $\kappa$ B $[59,60]$. Stimulation of LRRK2 results in the formation of tau oligomers, which stimulate cell death signaling [61,62]. LRRK2 modulates the traffic of certain vesicles and its overexpression leads to the activation of inflammatory cytokines [63].

\section{Parkinson's Disease and Glutamatergic Pathway}

Numerous studies have observed the association between glutamate-mediated excitotoxicity and PD $[14,64]$. PARK2 is an E3 ubiquitin ligase parkin-encoding gene and its mutation leads to PD. PARK2 mutations are associated with abnormal small parkin protein which is dysregulated and degraded. Parkin is involved in the stability of glutamatergic synapses. In PD, proliferation of glutamatergic synapses with excitotoxicity are involved by parkin mutations [65]. Glutamate excitotoxicity is correlated with the increase of Bax and p53 and the decrease of Bcl-2 [66]. The apoptosis attributed to glutamate is preceded by an upregulation in activator protein-1 (AP-1) due to the stimulation of c-Jun N-terminal kinase (JNK) and p38 mitogen-activated protein kinase (MAP kinase) and phosphorylation of c-Jun (Ser63) and p53 (Ser15) [67].

\section{WNT/ $\beta$-Catenin Pathway}

The name WNT is derived from Wingless Drosophila melanogaster and its mouse homolog Int. WNT/ $\beta$-catenin pathway is implicated in numerous signaling and regulating pathways, including embryogenesis, cell proliferation, migration and polarity, apoptosis, and organogenesis [68]. However, during numerous pathological states, the WNT/ $\beta$ catenin pathway can be dysregulated, such as inflammatory, metabolic and neurological disorders, tissue fibrosis and cancers [69].

The WNT pathway is one of the member of the secreted lipid-modified glycoproteins family [70]. WNT ligands are produced by neurons and immune cells in the central nervous system [71]. Control of the WNT/ $\beta$-catenin pathway implicates, embryonic development, cell fate, epithelial-mesenchymal transition (EMT), metabolism. WNT pathway dysregula- 
tion contributes to several neurodegenerative diseases including PD [6,72-74]. The WNT pathway has a main stage which is the $\beta$-catenin/T-cell factor/lymphoid enhancer factor (TCF/LEF). Accumulation of $\beta$-catenin in the cytoplasm is modulated by the destruction complex composed by AXIN, glycogen synthase kinase-3 (GSK-3 $\beta$ ) and tumor suppressor adenomatous polyposis coli (APC). In absence of WNT ligands, this destruction complex leads to hyper-phosphorylation of the cytoplasmic $\beta$-catenin and involves its proteasomal degradation. In contrast, in their presence, the WNT ligands complex to Frizzled (FZL) and LDL receptor-related protein 5/6 (LRP 5/6) to stop the action of the destruction complex and to prevent the proteasomal $\beta$-catenin degradation. B-catenin translocates to the nucleus to bind to TCF/LEF. This phenomenon stimulates the WNT target genes [75-77].

GSK-3 $\beta$ is one of the main inhibitors of the WNT / $\beta$-catenin pathway [78-83]. GSK$3 \beta$, an intracellular serine-threonine kinase, is a major controller and inhibitor of the WNT pathway [84]. It is implicated in the regulation of numerous pathophysiological pathways, including cell membrane signaling, cell polarity, and inflammation [85-87]. GSK$3 \beta$ directly inhibits cytoplasmic $\beta$-catenin and stabilizes it leading to its nuclear migration. Inflammation is an age-related phenomenon associated with stimulation of GSK-3 $\beta$ activity and the diminution of the WNT/ $\beta$-catenin signaling [88] (Figure 1).

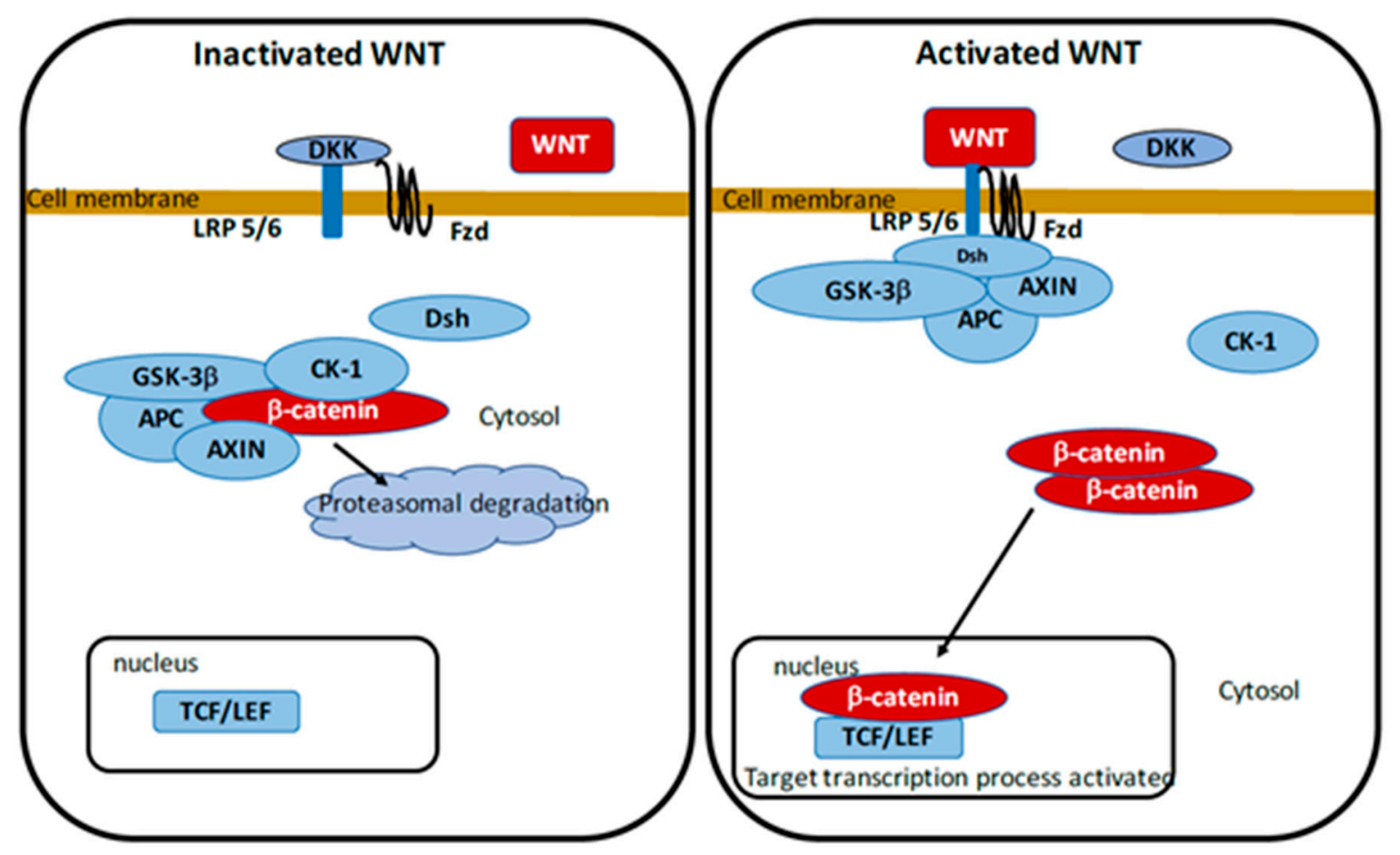

Figure 1. Activated and deactivated WNT pathway.

\subsection{Parkinson's Disease and WNT/ $\beta$-Catenin Pathway}

Alteration of the WNT pathway is concomitant with the emergence of PD [7,8]. WNT signaling abnormalities are considered to be markers for the development of PD [9]. Multiple altered biological phenomena in PD are under the control of the WNT pathway, including microtubule stability, axonal function, and membrane trafficking $[89,90]$. The Frizzled-1/ $\beta$-catenin pathway, directly controlled by WNT1, is responsible for the modulation of dopaminergic neuron-astrocyte crosstalk in the midbrain [91]. Under physiological conditions, LRRK2 binds to the WNT family and disheveled proteins (DSH) to inhibit the $\beta$-catenin destruction complex and to stimulate the WNT pathway [9]. In most cases, PD is an idiopathic form. However, familial PDs are often referred to PARK genes. Mutations in PARKs, encoding the leucine-rich repeat kinase 2 (LRRK2), have been shown to be a cause of familial forms of PD [92]. Decreased activity of the WNT pathway associated with decreased LRRK2-LRP5/6 binding affinity are caused by LRRK2 mutations [93]. 
Parkin is an E3 ubiquitin ligase encoded by the PARK2 gene. The genetic damage of parkin is responsible for the development of PD and works as repressors of $\beta$-catenin promoting ubiquitination and degradation of the latter [8]. DKK1 and GSK-3 $\beta$ are stimulated in PD [94]. PD mouse models exhibit crosstalk between inflammation, OS and WNT/ $\beta$-catenin payhway [95].

\subsection{WNT/ $\beta$-Catenin Pathway and Oxidative Stress}

Forkhead box class $\mathrm{O}$ (FoxO) transcription factors are main intracellular controllers of numerous metabolic signaling such as glucose production, and the cellular response to oxidative stress [96]. ROS is associated with the inhibition of the WNT pathway by diverting $\beta$-catenin from TCF/LEF to FoxO [97]. This leads to the accumulation and binding of $\beta$-catenin to FoxO as a cofactor, and in increasing FoxO transcriptional activity in the nucleus [98,99]. FoxO stimulates apoptotic genes [100-102]. FoxO3a stops the cellcycle by stimulating of the production of the cyclin-dependent kinase inhibitor p27 kip 1 and the inhibition of cyclin D1 expression $[103,104]$. The activation of FoxO leads to apoptosis induction [105]. However, the activation of the WNT pathway can downregulate FoxO3a in the cytosol to prevent the loss of mitochondrial membrane permeability, cytochrome c release, Bad phosphorylation, and activation of caspases which activates ROS production and oxidative stress [106].

\subsection{WNT/B-Catenin Pathway and Inflammation}

The stimulation of the WNT pathway cascade restrains inflammation and leads to the neuroprotection via interactions between microglia/macrophages and astrocytes [91,107]. Several studies have shown a negative crosstalk between WNT/ $\beta$-catenin pathway and NF- $\kappa$ B signaling pathway, one of the main marker of inflammation [108]. The NF- $\kappa$ B transcription factor family belongs of five members in the cytosol under non-activated conditions: NF- $\kappa$ B 1 (p50/p105), NF- $\kappa$ B 2 (p52/p100), RelA (p65), RelB and c-Rel [109]. B-catenin can complex with RelA and p50 to diminish the activity of the NF- $k$ B signaling [110]. Moreover, by interacting with the PI3K, $\beta$-catenin inhibits the functional activity of NF- $\kappa$ B [111]. This inhibitory function of $\beta$-catenin on NF- $\kappa$ B activity has been observed in numerous cell types, such as fibroblasts, epithelial cells, hepatocytes and osteoblasts [108]. In parallel, the overactivation of GSK- $3 \beta$ leads to an inhibition of the $\beta$-catenin and then an activation of the NF- $\kappa$ B pathway [112]. The potential protective action of $\beta$-catenin was due to the activation of PI3K/Akt pathway and thus the reduction of TLR4-driven inflammatory response in hepatocytes [113]. NF- $\kappa$ B activation leads to the diminution of the complex $\beta$-catenin/TCF/LEF by the upregulation of LZTS2 in cancer cells [114]. DKK, a WNT inhibitor, was a target gene of the NF- $k \mathrm{~B}$ pathway leading to a negative feedback to diminish the $\beta$-catenin signaling [115]. Activated B-catenin inhibits the NF- $\kappa$ B -mediated transcription of pro-inflammatory genes. This effect is controlled by the GSK-3 $\beta$. GSK-3 $\beta$ is a direct inhibitor of the $\beta$-catenin levels and an activator of the NF- $\kappa$ B signaling $[116,117]$.

\subsection{WNT/B-Catenin Pathway and Glutamatergic Pathway}

$\beta$-Catenin activates EAAT2 an GS at the transcriptional level in progenitor-derived astrocytes through the activation of TCF/LEF [118]. The knockdown of $\beta$-catenin leads to the diminution of EAAT2 and GS expression in prefrontal cortex [119]. In astrocytes, the inhibition of $\beta$-catenin is associated with diminution of both EAAT2 and GS expression [120]. The dysregulation of the WNT/ $\beta$-catenin pathway induces a glutamate excitotoxicity resulting in the increase of both inflammation and exudative stress [120].

\section{Parkinson's Disease: Interactions between WNT/ $\beta$-Catenin Pathway and Lithium}

A recent study has shown that mutant murine models of PD presented increased GSK- $3 \beta$ activity and thus its inhibition could be a treatment of perseverative behaviors (Figure 2). 


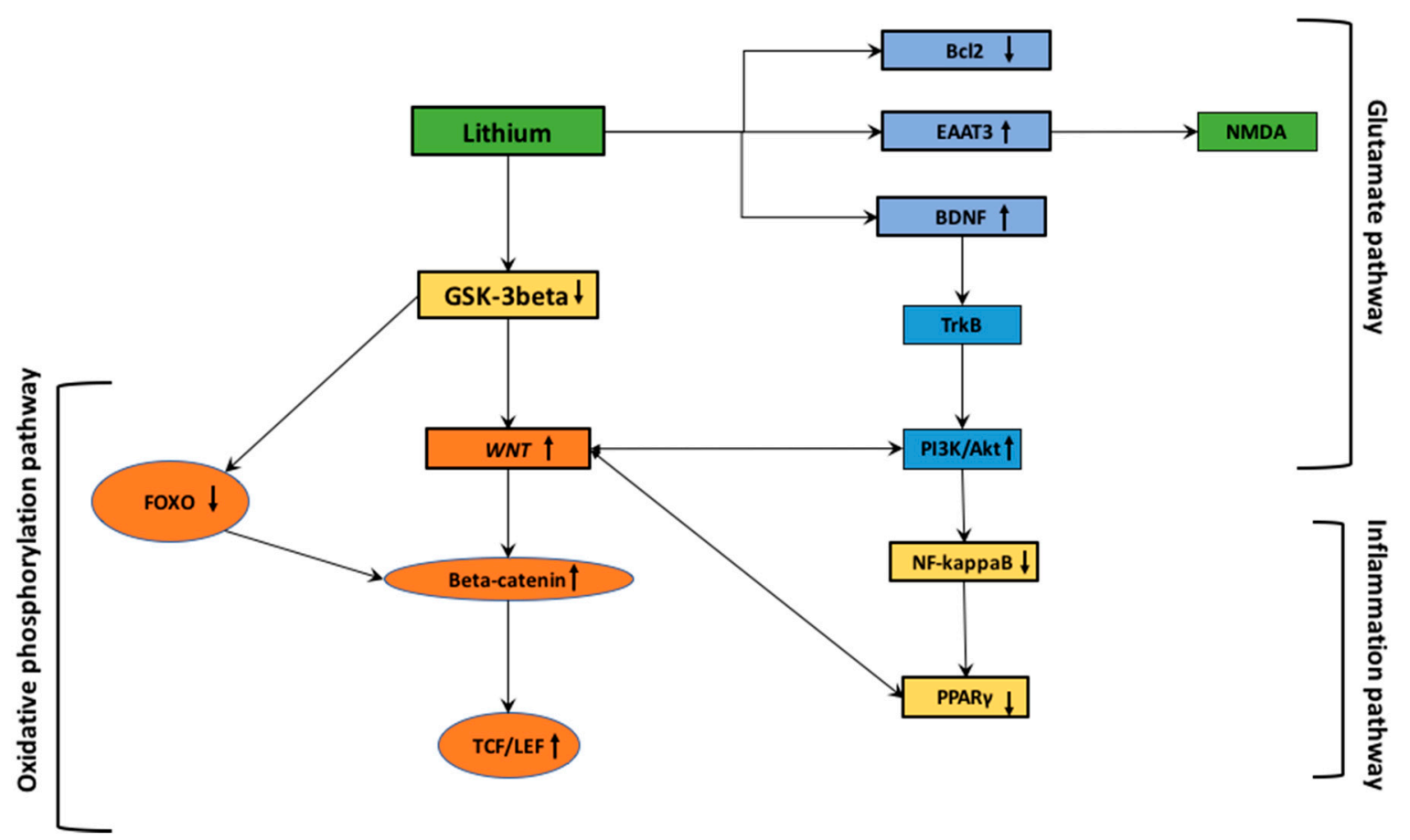

Figure 2. Lithium interactions with oxidative stress, inflammation and glutamatergic pathways.

Glycogen synthase kinase-3 $\beta$ (GSK-3 $\beta$ ) is a serine/threonine kinase which is involved in numerous intracellular signaling pathways. Dysfunction of GSK-3 $\beta$ is involved in the pathogenesis of several diseases, including neuropsychiatric disorders [121]. GSK-3 $\beta$ is a regulator of several pathways such as inflammation, neuronal polarity or either cell membrane signaling [86]. GSK-3 $\beta$ downregulates the canonical WNT/ $\beta$-catenin pathway by inhibiting $\beta$-catenin cytosolic stabilization and its translocation in the nucleus [93]. Moreover, numerous studies have observed a link between neuro-inflammation and the augmentation of the GSK-3 $\beta$ activity and in parallel the decrease of the WNT/ $\beta$-catenin pathway and the protein kinase B (Akt) pathway [78].

Lithium at concentrations of 1 to $2 \mathrm{mM}$ can inhibit GSK-3 $\beta$ activity [122-124]. Lithium reduces GSK-3 $\beta$ activity by increasing the inhibitory phosphorylation of GSK $3 \beta$ and through a direct activation of the Akt pathway. The activation of Akt modulates forkhead bow class $\mathrm{O}$ (FOXO), Bcl-2 associated death protein (Bad) (a pro-apoptotic protein of the Bcl-2 family) $[125,126]$. Therapeutic concentrations of the GSK-3 $\beta$ inhibitor lithium leads to the increase in $\beta$-catenin levels $[127,128]$ and then promotes $\beta$-catenin transcriptional activity $[129,130]$. In brain of mouse, the over-expression of $\beta$-catenin levels mimic anti-depressant-like effects of lithium [131] while the knockout of $\beta$-catenin leads to a depression-like phenotype $[132,133]$.

Several studies have shown the neuroprotective actions of lithium in models of PD $[14,64,134-139]$. Moreover, lithium inhibits GSK-3 $\beta$ thought its phosphorylation at Ser9 resulting in reduction of $p$-tau formation $[140,141]$. The inhibition of GSK-3 $\beta$ by lithium also result in the increase of $\beta$-catenin levels to enhance dopaminergic cell viability and then the reduction of $\alpha$-synuclein $[142,143]$. PD patients show low CSF A $\beta$ levels reflecting high brain $A \beta$ deposition [144]. A $\beta$ inhibits Akt and stimulates c-Abelson kinase (c-Abl) which increases p-tau formation through the activation of GSK-3 $\beta$ [6]. Lithium inhibits A $\beta$ 's effects by inhibiting GSK-3 $\beta$ and cdk5 [145]. Degradation of intracellular proteins, including $\alpha$-synuclein and p-tau, was influenced by autophagy-lysosomal pathway [146]. Akt/mTOR pathway can regulate authophagy [147].

The accumulation of $\alpha$-synuclein leads to impaired autophagy and lysosomal functions [148]. Lithium can reduce $\alpha$-synuclein aggregation by targeting autophagy through the Akt/mTOR pathway [149]. Enzymes have been proposed as potential targets of lithium 
action, such as inositol monophosphatase (IMPase), a family of structurally related phosphomonoesterases and the GSK-3 $\beta$ [149]. Lithium inhibits GSK-3 $\beta$ to reduce autophagy by activating the PI3K/Akt/mTOR pathway [150]. Lithium is a direct inhibitor of GSK-3 $\beta$, which has a main role in oxidative stress through its inhibitory action on the WNT pathway. GSK-3 $\beta$ activity is regulated by site-specific phosphorylation. The activity of GSK3- $\beta$ is upregulated by phosphorylation on the Tyr (216) residue, and conversely, phosphorylation on Ser(9) inhibits GSK-3 $\beta$ activity. In epidermal cells, ultraviolet B activated autophagy as a protective response and inhibited GSK3- $\beta$ activation by simultaneously enhancing phosphorylation at Ser [151]. IMPase catalyzes the hydrolysis of inositol monophosphate (IP1) into free inositol required for the phosphoinositol signaling pathway [152]. Lithium affects this pathway by inhibiting IMPase, leading to free inositol depletion, which in turn decreases myo-inositol-1,4,5-trisphosphate (IP3) levels. Increased inositol or IP3 levels inhibit autophagy, which reverse lithium's effect [153]. IP3 and the stimulation of its receptor have been seen to suppress autophagy [154]. The mitochondrial complex I inhibitors, 1-methyl-4-phenyl-1,2,3,6-tetrahydropyridine (MPTP), and rotenone were extensively used as neurotoxins to induce parkinsonian symptoms [155]. MPTP, mediated by GSK3- $\beta$, have been reported to enhance conversion of soluble $\alpha$-synuclein to insoluble $\alpha$-synuclein aggregates. Lithium administration can suppress MPTP activity and expression [156]. Lithium treatment ameliorates rotenone-induced toxicity in human neuroblastoma SH-SY5Y cells, which shows nuclear fragmentation and apoptosis [157]. A decrease in mitochondrial membrane potential, reduced reactive oxygen species generation and an increased number of lysosomes and autophagic vacuolar organelles was observed with $0.2 \mu \mathrm{m}$ to $10 \mathrm{mM}$ lithium administration [158]. Lithium administration protects against oxidative stress in the presence of $\alpha$-synuclein A53T expression [134]. Moreover, lithium increases proteasomal activity which could explain the lithium-mediated reductions in $\alpha$-synuclein and nitration/oxidization levels [159].

\subsection{Lithium and Oxidative Stress}

Energy and glucose metabolisms involved during oxidative stress are mainly controlled by the intracellular FOXO transcription factors (FOXO1, 3a, 4) [96]. The interaction between $\beta$-catenin and FOXO transcription factors promotes cell quiescence and cell cycle arrest. B-catenin blocks its transcriptional complex with TCF/LEF through the interaction with FOXO-induced ROS [97]. B-catenin does not translocate to the nucleus and thus accumulates in the cytosol leading to the inactivation of the WNT/ $\beta$-catenin pathway $[98,99]$. Previous study has found that lithium can reduce FOXO3a transcriptional activity and can decrease the active FOXO3a level [160]. Thus, by inactivating GSK3- $\beta$, activating the WNT/ $\beta$-catenin pathway and reducing the FOXO, lithium could participate to the reduction of oxidative stress.

Furthermore, numerous in vitro studies have shown that lithium administration could diminish hydrogen peroxide-induced cell death as well as obstruct lipid peroxidation and protein oxidation in cortical cells [134,161-165]. Moreover, lithium can act as an anti-oxidant by increasing CHS levels in neurons of rat dopaminergic N27 [134,162]. Moreover, the ability of lithium to act as an anti-oxidant was associate with the increase in GSH levels [134,162].

\subsection{Lithium and Inflammation}

Through the downregulation of GSK-3 $\beta$ activity and thus, the upregulation of the WNT / $\beta$-catenin pathway, the lithium administration could involve a diminution of the neuro-inflammation by acting on the NF- $\kappa$ B pathway (Figure 2 ). The stimulation of the WNT pathway cascade restrains inflammation and leads to the neuroprotection via interactions between microglia/macrophages and astrocytes [91,107].

Numerous studies have shown a negative crosstalk between WNT/ $\beta$-catenin pathway and NF- $\kappa$ B signaling pathway [108]. The NF- $\kappa$ B transcription factor family belongs of five members in the cytosol under non-activated conditions: NF- $\kappa$ B 1 (p50/p105), NF- $\kappa$ B 2 
(p52/p100), RelA (p65), RelB and c-Rel [109]. B-catenin can form a complex with RelA and p50 to decrease the activity of the NF- $\kappa$ B signaling [110]. Moreover, by interacting with the PI3K, $\beta$-catenin inhibits the functional activity of NF- $\kappa B$ [111]. This inhibitory function of $\beta$-catenin on NF- $\kappa$ B activity has been observed in numerous cell types, such as fibroblasts, epithelial cells, hepatocytes and osteoblasts [108]. In parallel, the overactivation of GSK-3 $\beta$ leads to an inhibition of the $\beta$-catenin and then an activation of the NF- $\kappa$ B pathway [112]. The potential protective action of $\beta$-catenin was due to the activation of PI3K/Akt pathway and thus the reduction of TLR4-driven inflammatory response in hepatocytes [113]. NF- $\kappa \mathrm{B}$ activation leads to the inhibition of the complex $\beta$-catenin/TCF/LEF by the upregulation of LZTS2 in cancer cells [114]. DKK, a WNT inhibitor, was a target gene of the NF- $\kappa \mathrm{B}$ pathway leading to a negative feedback to diminish the $\beta$-catenin signaling [115].

A recent study has presented that the WNT pathway appeared to be one of the main mechanisms of action of lithium in adipose cells, and this interaction is done by the inhibition of PPAR $\gamma$ expression [166]. PPARs are ligand-activated transcription factors which bind PPRE (PPAR-response elements). PPARs are involved in numerous pathophysiological processes, such as cell differentiation, proteins metabolism, lipids metabolism, carcinogenesis [167,168], adipocyte differentiation, insulin sensitivity and inflammation $[169,170]$. PPAR $\gamma$ ligands, such as thiazolidinediones (TZDs), are able to decrease the inflammatory activity [171].

A negative crosstalk has been well described between PPAR $\gamma$ and the WNT pathway [172-175]. The PI3K/Akt pathway, which is positively induced by $\beta$-catenin $[176,177]$, acts by phosphorylating GSK-3 $\beta$ to negatively regulate PPAR $\gamma$ expression [178]. PPAR $\gamma$ agonists decrease $\beta$-catenin expression by overactivating GSK-3 $\beta$ [179]. Moreover, PPAR $\gamma$ agonists stimulate Dickkopf-1 (DKK1) activity to diminish the canonical WNT/ $\beta$-catenin pathway and then to decrease fibroblasts differentiation [180]. Moreover, PPAR $\gamma$ agonists stimulate GSK-3 $\beta$ to inhibit $\beta$-catenin expression [179].

\subsection{Lithium and Glutamatergic Pathway}

The administration of lithium was also associated with an influence on the levels of pro-apoptotic proteins (Figure 2). Bax, referred to as Bcl-2 associated C protein, is a key modulator promoting apoptosis by binding to and antagonizing Bcl-2 protein. The tumor suppressor protein, p53, targets Bcl-2 and Bax and then promotes growth arrest and cell death in response to cell damage [181].

Numerous studies have shown that the neuroprotective actions of lithium may be associated with increased levels of Bcl-2. Lithium therapy of cultured cerebellar granule cells stimulated the levels of mRNA and Bcl-2 protein, the level of Bcl-2/Bax protein level was increased by 5-fold after treatment during [66]. Stimulation of Bcl-2 expression induces neurogenesis within the hippocampus and entorhinal cortex in mice by increasing axon diameters and neurite growth on the CA3 area of the hippocampus and stimulates the myelination in the entorhinal cortex [182]. Lithium works by activating anti-apoptotic Bcl-2 levels and decreasing Bax expression [183]. The phosphorylation of Bcl-2 with serine 70 is essential for a complete anti-apoptotic action [184]. Several studies have shown that lithium possesses this ability [185]. Lithium decreases Bcl-2 dephosphorylation and caspase-2 stimulation by reducing expression of protein phosphatase-2A [185].

The excitotoxicity of glutamate has been strongly linked to the increase in the expression of Bax and p53 but also to the decrease in the expression of Bcl-2 [66]. The apoptotic process attributed to glutamate is preceded by the increased expression of activator-1 (AP-1) involved by stimulation of c-Jun N-terminal kinase (JNK) and mitogen-activated protein kinase p38 (MAP kinase) and phosphorylation of c-Jun and p53 [67].

By inhibiting GSK-3 $\beta$ activity, lithium acts as a powerful regulator of EAAT3 and therefore on the regulation of NMDA receptors [186]. In addition, a potential pathway could be the inhibition of presynaptic NMDA receptors and therefore the activation of postsynaptic AMPA receptors by the release of glutamate. This mechanism is followed by the activation of calcium influx and the secretion of brain-derived neurotrophic factor 
(BDNF). Thus, BDNF stimulates receptor tyrosine kinase B (TrkB) leading to neuronal survival and differentiation [187].

Activated BDNF-TrkB signaling leads to stimulate the Akt/mTOR pathway causing activation of the $W N T / \beta$-catenin pathway and improvement of synaptic proteins [188]. Low therapeutic level of lithium activates BDNF-TrkB signaling and then Akt/mTOR signaling to protect neurons from glutamate excitotoxicity [189]. Lithium inhibits excessive glutamate, NMDA receptor-mediated calcium influx into neurons, and reduces phosphorylation of the NR2B tyrosine subunit by Src/Fyn kinase [190].

\title{
7. Conclusions
}

Currently, few studies have investigated lithium as possible alternative therapeutic way to treat PD patients. Nevertheless, lithium could appear to be interesting against PD because of its potential inhibitory effect on oxidative stress, inflammation and glutamatergic pathway and this with few adverse effects at low doses. WNT/ $\beta$-catenin pathway is decreased PD. Through, the stimulation of the WNT/ $\beta$-catenin pathway, by the inhibition of GSK-3 $\beta$, lithium, could be an innovative therapeutic way in PD. Future prospective studies could focus on lithium and its different and multiple interactions in PD. Autophagy is a "self-eating" mechanism which is induced to catabolize cellular substrates to generate energy. This process is responsible for the quality control of essential cellular components by purging cell of damaged organelles, such as peroxisomes and mitochondria, and by degrading aggregate-prone proteins [191]. The dysfunction of autophagy was observed in several neurodegenerative diseases, including Parkinson's disease, Alzheimer's disease, amyotrophic lateral sclerosis, Huntington's disease [192]. These neurodegenerative disease also present a dysregulation of the WNT/ $\beta$-catenin pathway [6]. Autophagy and WNT $/ \beta$ catenin pathway are mainly associated [193] Thus, even if this article presents the interest of lithium in PD, lithium could be also of interest of other neurodegenerative disease [139].

Author Contributions: All the authors have contributed equally and substantially to the work. All authors have read and agreed to the published version of the manuscript.

Funding: This research received no external funding.

Institutional Review Board Statement: Not applicable.

Informed Consent Statement: Not applicable.

Data Availability Statement: Not applicable.

Conflicts of Interest: The authors declare no conflict of interest.

\begin{abstract}
Abbreviations
GSK-3 $\beta$ : Glycogen synthase kinase-3 $\beta$; LRP 5/6: Low-density lipoprotein receptor-related protein 5/6; NF- $\kappa$ B: nuclear factor kappaB; PPAR $\gamma$ : Peroxisome proliferator-activated receptor gamma; PI3K-Akt: Phosphatidylinositol 3-kinase-protein kinase B; TCF/LEF: T-cell factor/lymphoid enhancer factor; TNF- $\alpha$ : tumor necrosis factor alpha; PD: parkinson's disease.
\end{abstract}

\section{References}

1. Braak, H.; Ghebremedhin, E.; Rüb, U.; Bratzke, H.; Del Tredici, K. Stages in the Development of Parkinson's Disease-Related Pathology. Cell Tissue Res. 2004, 318, 121-134. [CrossRef]

2. Grinberg, L.T.; Rueb, U.; di Lorenzo Alho, A.T.; Heinsen, H. Brainstem Pathology and Non-Motor Symptoms in PD. J. Neurol. Sci. 2010, 289, 81-88. [CrossRef]

3. Maguire-Zeiss, K.A.; Federoff, H.J. Future Directions for Immune Modulation in Neurodegenerative Disorders: Focus on Parkinson's Disease. J. Neural Transm. Vienna Austria 1996 2010, 117, 1019-1025. [CrossRef]

4. Yin, F.; Boveris, A.; Cadenas, E. Mitochondrial Energy Metabolism and Redox Signaling in Brain Aging and Neurodegeneration. Antioxid. Redox Signal. 2014, 20, 353-371. [CrossRef]

5. Kim, G.H.; Kim, J.E.; Rhie, S.J.; Yoon, S. The Role of Oxidative Stress in Neurodegenerative Diseases. Exp. Neurobiol. 2015, 24, 325-340. [CrossRef] 
6. Vallée, A.; Lecarpentier, Y.; Guillevin, R.; Vallée, J.-N. Thermodynamics in Neurodegenerative Diseases: Interplay between Canonical WNT/Beta-Catenin Pathway-PPAR Gamma, Energy Metabolism and Circadian Rhythms. Neuromolecular Med. 2018, 20, 174-204. [CrossRef]

7. Parish, C.L.; Castelo-Branco, G.; Rawal, N.; Tonnesen, J.; Sorensen, A.T.; Salto, C.; Kokaia, M.; Lindvall, O.; Arenas, E. Wnt5aTreated Midbrain Neural Stem Cells Improve Dopamine Cell Replacement Therapy in Parkinsonian Mice. J. Clin. Invest. 2008, 118, 149-160. [CrossRef]

8. Rawal, N.; Corti, O.; Sacchetti, P.; Ardilla-Osorio, H.; Sehat, B.; Brice, A.; Arenas, E. Parkin Protects Dopaminergic Neurons from Excessive Wnt/Beta-Catenin Signaling. Biochem. Biophys. Res. Commun. 2009, 388, 473-478. [CrossRef]

9. Berwick, D.C.; Harvey, K. The Importance of Wnt Signalling for Neurodegeneration in Parkinson's Disease. Biochem. Soc. Trans. 2012, 40, 1123-1128. [CrossRef]

10. Smith, L.A.; Cornelius, V.; Warnock, A.; Bell, A.; Young, A.H. Effectiveness of Mood Stabilizers and Antipsychotics in the Maintenance Phase of Bipolar Disorder: A Systematic Review of Randomized Controlled Trials. Bipolar Disord. 2007, 9, 394-412. [CrossRef]

11. Baldessarini, R.J.; Tondo, L.; Davis, P.; Pompili, M.; Goodwin, F.K.; Hennen, J. Decreased Risk of Suicides and Attempts during Long-Term Lithium Treatment: A Meta-Analytic Review. Bipolar Disord. 2006, 8, 625-639. [CrossRef] [PubMed]

12. Zhu, Z.-F.; Wang, Q.-G.; Han, B.-J.; William, C.P. Neuroprotective Effect and Cognitive Outcome of Chronic Lithium on Traumatic Brain Injury in Mice. Brain Res. Bull. 2010, 83, 272-277. [CrossRef] [PubMed]

13. Donaldson, I.M.; Cuningham, J. Persisting Neurologic Sequelae of Lithium Carbonate Therapy. Arch. Neurol. 1983, 40, 747-751. [CrossRef] [PubMed]

14. Lazzara, C.A.; Kim, Y.-H. Potential Application of Lithium in Parkinson's and Other Neurodegenerative Diseases. Front. Neurosci. 2015, 9, 403. [CrossRef]

15. Aprahamian, I.; Santos, F.S.; dos Santos, B.; Talib, L.; Diniz, B.S.; Radanovic, M.; Gattaz, W.F.; Forlenza, O.V. Long-Term, Low-Dose Lithium Treatment Does Not Impair Renal Function in the Elderly: A 2-Year Randomized, Placebo-Controlled Trial Followed by Single-Blind Extension. J. Clin. Psychiatry 2014, 75, e672-678. [CrossRef] [PubMed]

16. Baird-Gunning, J.; Lea-Henry, T.; Hoegberg, L.C.G.; Gosselin, S.; Roberts, D.M. Lithium Poisoning. J. Intensive Care Med. 2017, 32, 249-263. [CrossRef]

17. Maddala, R.N.M.; Ashwal, A.J.; Rao, M.S.; Padmakumar, R. Chronic Lithium Intoxication: Varying Electrocardiogram Manifestations. Indian J. Pharmacol. 2017, 49, 127-129. [CrossRef] [PubMed]

18. Peet, M.; Pratt, J.P. Lithium. Current Status in Psychiatric Disorders. Drugs 1993, 46, 7-17. [CrossRef]

19. Ferensztajn-Rochowiak, E.; Chłopocka-Woźniak, M.; Rybakowski, J.K. Ultra-Long-Term Lithium Therapy: All-Important Matters and a Case of Successful 50-Year Lithium Treatment. Rev. Bras. Psiquiatr. Sao Paulo Braz. 1999 2020. [CrossRef]

20. Abou-Saleh, M.T.; Coppen, A. The Efficacy of Low-Dose Lithium: Clinical, Psychological and Biological Correlates. J. Psychiatr. Res. 1989, 23, 157-162. [CrossRef]

21. Straten, G.; Saur, R.; Laske, C.; Gasser, T.; Annas, P.; Basun, H.; Leyhe, T. Influence of Lithium Treatment on GDNF Serum and CSF Concentrations in Patients with Early Alzheimer's Disease. Curr. Alzheimer Res. 2011, 8, 853-859. [CrossRef] [PubMed]

22. Post, R.M. The New News about Lithium: An Underutilized Treatment in the United States. Neuropsychopharmacol. Off. Publ. Am. Coll. Neuropsychopharmacol. 2018, 43, 1174-1179. [CrossRef] [PubMed]

23. Giordano, S.; Darley-Usmar, V.; Zhang, J. Autophagy as an Essential Cellular Antioxidant Pathway in Neurodegenerative Disease. Redox Biol. 2014, 2, 82-90. [CrossRef]

24. Wang, X.; Zhou, Y.; Gao, Q.; Ping, D.; Wang, Y.; Wu, W.; Lin, X.; Fang, Y.; Zhang, J.; Shao, A. The Role of Exosomal MicroRNAs and Oxidative Stress in Neurodegenerative Diseases. Oxid. Med. Cell. Longev. 2020, 2020, 3232869. [CrossRef] [PubMed]

25. Jimenez-Moreno, N.; Lane, J.D. Autophagy and Redox Homeostasis in Parkinson's: A Crucial Balancing Act. Oxid. Med. Cell. Longev. 2020, 2020, 8865611. [CrossRef] [PubMed]

26. Li, X.; Feng, Y.; Wang, X.-X.; Truong, D.; Wu, Y.-C. The Critical Role of SIRT1 in Parkinson's Disease: Mechanism and Therapeutic Considerations. Aging Dis. 2020, 11, 1608-1622. [CrossRef] [PubMed]

27. Dorszewska, J.; Kowalska, M.; Prendecki, M.; Piekut, T.; Kozłowska, J.; Kozubski, W. Oxidative Stress Factors in Parkinson's Disease. Neural Regen. Res. 2021, 16, 1383-1391. [CrossRef]

28. Cuevas, E.; Burks, S.; Raymick, J.; Robinson, B.; Gómez-Crisóstomo, N.P.; Escudero-Lourdes, C.; Lopez, A.G.G.; Chigurupati, S.; Hanig, J.; Ferguson, S.A.; et al. Tauroursodeoxycholic Acid (TUDCA) Is Neuroprotective in a Chronic Mouse Model of Parkinson's Disease. Nutr. Neurosci. 2020, 1-18. [CrossRef] [PubMed]

29. Mat Taib, C.N.; Mustapha, M. MPTP-Induced Mouse Model of Parkinson's Disease: A Promising Direction of Therapeutic Strategies. Bosn. J. Basic Med. Sci. 2020. [CrossRef]

30. Franco-Iborra, S.; Vila, M.; Perier, C. The Parkinson Disease Mitochondrial Hypothesis: Where Are We At? Neurosci. Rev. J. Bringing Neurobiol. Neurol. Psychiatry 2016, 22, 266-277. [CrossRef]

31. Luque-Contreras, D.; Carvajal, K.; Toral-Rios, D.; Franco-Bocanegra, D.; Campos-Peña, V. Oxidative Stress and Metabolic Syndrome: Cause or Consequence of Alzheimer's Disease? Oxid. Med. Cell. Longev. 2014, 2014, 497802. [CrossRef] [PubMed]

32. Benilova, I.; Karran, E.; De Strooper, B. The Toxic A $\beta$ Oligomer and Alzheimer's Disease: An Emperor in Need of Clothes. Nat. Neurosci. 2012, 15, 349-357. [CrossRef] [PubMed] 
33. Sochocka, M.; Koutsouraki, E.S.; Gasiorowski, K.; Leszek, J. Vascular Oxidative Stress and Mitochondrial Failure in the Pathobiology of Alzheimer's Disease: A New Approach to Therapy. CNS Neurol. Disord. Drug Targets 2013, 12, 870-881. [CrossRef] [PubMed]

34. Islam, M.T. Oxidative Stress and Mitochondrial Dysfunction-Linked Neurodegenerative Disorders. Neurol. Res. 2017, 39, 73-82. [CrossRef]

35. Schapira, A.H.V. Mitochondria in the Aetiology and Pathogenesis of Parkinson's Disease. Lancet Neurol. 2008, 7, 97-109. [CrossRef]

36. Blesa, J.; Trigo-Damas, I.; Quiroga-Varela, A.; Jackson-Lewis, V.R. Oxidative Stress and Parkinson's Disease. Front. Neuroanat. 2015, 9, 91. [CrossRef]

37. Ames, B.N.; Shigenaga, M.K.; Hagen, T.M. Oxidants, Antioxidants, and the Degenerative Diseases of Aging. Proc. Natl. Acad. Sci. USA 1993, 90, 7915-7922. [CrossRef]

38. Coyle, J.T.; Puttfarcken, P. Oxidative Stress, Glutamate, and Neurodegenerative Disorders. Science 1993, 262, 689-695. [CrossRef]

39. Surace, M.J.; Block, M.L. Targeting Microglia-Mediated Neurotoxicity: The Potential of NOX2 Inhibitors. Cell. Mol. Life Sci. CMLS 2012, 69, 2409-2427. [CrossRef]

40. Dias, V.; Junn, E.; Mouradian, M.M. The Role of Oxidative Stress in Parkinson's Disease. J. Park. Dis. 2013, 3, 461-491. [CrossRef]

41. Puspita, L.; Chung, S.Y.; Shim, J.-W. Oxidative Stress and Cellular Pathologies in Parkinson's Disease. Mol. Brain 2017, 10, 53. [CrossRef] [PubMed]

42. Jenner, P. Oxidative Stress in Parkinson's Disease. Ann. Neurol. 2003, 53 (Suppl. 3). [CrossRef] [PubMed]

43. Rahimmi, A.; Khosrobakhsh, F.; Izadpanah, E.; Moloudi, M.R.; Hassanzadeh, K. N-Acetylcysteine Prevents Rotenone-Induced Parkinson's Disease in Rat: An Investigation into the Interaction of Parkin and Drp1 Proteins. Brain Res. Bull. 2015, 113, 34-40. [CrossRef] [PubMed]

44. Olanow, C.W.; Schapira, A.H.V.; LeWitt, P.A.; Kieburtz, K.; Sauer, D.; Olivieri, G.; Pohlmann, H.; Hubble, J. TCH346 as a Neuroprotective Drug in Parkinson's Disease: A Double-Blind, Randomised, Controlled Trial. Lancet Neurol. 2006, 5, 1013-1020. [CrossRef]

45. Lim, K.-L.; Tan, J.M.M. Role of the Ubiquitin Proteasome System in Parkinson's Disease. BMC Biochem. 2007, 8 (Suppl. 1), S13. [CrossRef]

46. Hassanzadeh, K.; Rahimmi, A. Oxidative Stress and Neuroinflammation in the Story of Parkinson's Disease: Could Targeting These Pathways Write a Good Ending? J. Cell. Physiol. 2018, 234, 23-32. [CrossRef]

47. McGeer, P.L.; Itagaki, S.; Boyes, B.E.; McGeer, E.G. Reactive Microglia Are Positive for HLA-DR in the Substantia Nigra of Parkinson's and Alzheimer's Disease Brains. Neurology 1988, 38, 1285-1291. [CrossRef]

48. Anglade, P.; Vyas, S.; Javoy-Agid, F.; Herrero, M.T.; Michel, P.P.; Marquez, J.; Mouatt-Prigent, A.; Ruberg, M.; Hirsch, E.C.; Agid, Y. Apoptosis and Autophagy in Nigral Neurons of Patients with Parkinson's Disease. Histol. Histopathol. 1997, $12,25-31$.

49. Gupta, A.; Dawson, V.L.; Dawson, T.M. What Causes Cell Death in Parkinson's Disease? Ann. Neurol. 2008, 64 (Suppl. 2), S3-S15. [CrossRef]

50. Glass, C.K.; Saijo, K.; Winner, B.; Marchetto, M.C.; Gage, F.H. Mechanisms Underlying Inflammation in Neurodegeneration. Cell 2010, 140, 918-934. [CrossRef]

51. Ramesh, G.; MacLean, A.G.; Philipp, M.T. Cytokines and Chemokines at the Crossroads of Neuroinflammation, Neurodegeneration, and Neuropathic Pain. Mediat. Inflamm. 2013, 2013, 480739. [CrossRef] [PubMed]

52. Tufekci, K.U.; Meuwissen, R.; Genc, S.; Genc, K. Inflammation in Parkinson's Disease. Adv. Protein Chem. Struct. Biol. 2012, 88, 69-132. [CrossRef] [PubMed]

53. Rocha, N.P.; de Miranda, A.S.; Teixeira, A.L. Insights into Neuroinflammation in Parkinson's Disease: From Biomarkers to Anti-Inflammatory Based Therapies. BioMed Res. Int. 2015, 2015, 628192. [CrossRef] [PubMed]

54. Shih, R.-H.; Wang, C.-Y.; Yang, C.-M. NF-KappaB Signaling Pathways in Neurological Inflammation: A Mini Review. Front. Mol. Neurosci. 2015, 8, 77. [CrossRef] [PubMed]

55. Mogi, M.; Togari, A.; Kondo, T.; Mizuno, Y.; Komure, O.; Kuno, S.; Ichinose, H.; Nagatsu, T. Caspase Activities and Tumor Necrosis Factor Receptor R1 (P55) Level Are Elevated in the Substantia Nigra from Parkinsonian Brain. J. Neural Transm. Vienna Austria 1996 2000, 107, 335-341. [CrossRef]

56. Shimoji, M.; Pagan, F.; Healton, E.B.; Mocchetti, I. CXCR4 and CXCL12 Expression Is Increased in the Nigro-Striatal System of Parkinson's Disease. Neurotox. Res. 2009, 16, 318-328. [CrossRef]

57. Yacoubian, T.A.; Standaert, D.G. Targets for Neuroprotection in Parkinson's Disease. Biochim. Biophys. Acta 2009, 1792, 676-687. [CrossRef]

58. Gardet, A.; Benita, Y.; Li, C.; Sands, B.E.; Ballester, I.; Stevens, C.; Korzenik, J.R.; Rioux, J.D.; Daly, M.J.; Xavier, R.J.; et al. LRRK2 Is Involved in the IFN-Gamma Response and Host Response to Pathogens. J. Immunol. Baltim. Md 1950 2010, 185, 5577-5585. [CrossRef]

59. Russo, I.; Berti, G.; Plotegher, N.; Bernardo, G.; Filograna, R.; Bubacco, L.; Greggio, E. Leucine-Rich Repeat Kinase 2 Positively Regulates Inflammation and down-Regulates NF- $\kappa$ B P50 Signaling in Cultured Microglia Cells. J. Neuroinflamm. 2015, 12, 230. [CrossRef]

60. López de Maturana, R.; Lang, V.; Zubiarrain, A.; Sousa, A.; Vázquez, N.; Gorostidi, A.; Águila, J.; López de Munain, A.; Rodríguez, M.; Sánchez-Pernaute, R. Mutations in LRRK2 Impair NF- $\kappa$ B Pathway in IPSC-Derived Neurons. J. Neuroinflammation 2016, 13, 295. [CrossRef]

61. Moussaud, S.; Jones, D.R.; Moussaud-Lamodière, E.L.; Delenclos, M.; Ross, O.A.; McLean, P.J. Alpha-Synuclein and Tau: Teammates in Neurodegeneration? Mol. Neurodegener. 2014, 9, 43. [CrossRef] [PubMed] 
62. Guerreiro, P.S.; Gerhardt, E.; Lopes da Fonseca, T.; Bähr, M.; Outeiro, T.F.; Eckermann, K. LRRK2 Promotes Tau Accumulation, Aggregation and Release. Mol. Neurobiol. 2016, 53, 3124-3135. [CrossRef] [PubMed]

63. Russo, I.; Bubacco, L.; Greggio, E. LRRK2 and Neuroinflammation: Partners in Crime in Parkinson's Disease? J. Neuroinflammation 2014, 11, 52. [CrossRef] [PubMed]

64. Guttuso, T.; Andrzejewski, K.L.; Lichter, D.G.; Andersen, J.K. Targeting Kinases in Parkinson's Disease: A Mechanism Shared by LRRK2, Neurotrophins, Exenatide, Urate, Nilotinib and Lithium. J. Neurol. Sci. 2019, 402, 121-130. [CrossRef] [PubMed]

65. Helton, T.D.; Otsuka, T.; Lee, M.-C.; Mu, Y.; Ehlers, M.D. Pruning and Loss of Excitatory Synapses by the Parkin Ubiquitin Ligase. Proc. Natl. Acad. Sci. USA 2008, 105, 19492-19497. [CrossRef] [PubMed]

66. Chen, R.W.; Chuang, D.M. Long Term Lithium Treatment Suppresses P53 and Bax Expression but Increases Bcl-2 Expression. A Prominent Role in Neuroprotection against Excitotoxicity. J. Biol. Chem. 1999, 274, 6039-6042. [CrossRef] [PubMed]

67. Chen, R.-W.; Qin, Z.-H.; Ren, M.; Kanai, H.; Chalecka-Franaszek, E.; Leeds, P.; Chuang, D.-M. Regulation of C-Jun N-Terminal Kinase, P38 Kinase and AP-1 DNA Binding in Cultured Brain Neurons: Roles in Glutamate Excitotoxicity and Lithium Neuroprotection. J. Neurochem. 2003, 84, 566-575. [CrossRef]

68. Loh, K.M.; van Amerongen, R.; Nusse, R. Generating Cellular Diversity and Spatial Form: Wnt Signaling and the Evolution of Multicellular Animals. Dev. Cell 2016, 38, 643-655. [CrossRef]

69. Oren, O; Smith, B.D. Eliminating Cancer Stem Cells by Targeting Embryonic Signaling Pathways. Stem Cell Rev. 2017, 13, 17-23. [CrossRef]

70. Al-Harthi, L. Wnt/ $\beta$-Catenin and Its Diverse Physiological Cell Signaling Pathways in Neurodegenerative and Neuropsychiatric Disorders. J. Neuroimmune Pharmacol. 2012, 7, 725-730. [CrossRef]

71. Marchetti, B.; Pluchino, S. Wnt Your Brain Be Inflamed? Yes, It Wnt! Trends Mol. Med. 2013, 19, 144-156. [CrossRef]

72. Lecarpentier, Y.; Claes, V.; Duthoit, G.; Hébert, J.-L. Circadian Rhythms, Wnt/Beta-Catenin Pathway and PPAR Alpha/Gamma Profiles in Diseases with Primary or Secondary Cardiac Dysfunction. Front. Physiol. 2014, 5, 429. [CrossRef] [PubMed]

73. Lecarpentier, Y.; Vallée, A. Opposite Interplay between PPAR Gamma and Canonical Wnt/Beta-Catenin Pathway in Amyotrophic Lateral Sclerosis. Front. Neurol. 2016, 7, 100. [CrossRef] [PubMed]

74. Vallée, A.; Lecarpentier, Y. Alzheimer Disease: Crosstalk between the Canonical Wnt/Beta-Catenin Pathway and PPARs Alpha and Gamma. Front. Neurosci. 2016, 10, 459. [CrossRef]

75. He, T.C.; Sparks, A.B.; Rago, C.; Hermeking, H.; Zawel, L.; da Costa, L.T.; Morin, P.J.; Vogelstein, B.; Kinzler, K.W. Identification of C-MYC as a Target of the APC Pathway. Science 1998, 281, 1509-1512. [CrossRef]

76. Shtutman, M.; Zhurinsky, J.; Simcha, I.; Albanese, C.; D’Amico, M.; Pestell, R.; Ben-Ze'ev, A. The Cyclin D1 Gene Is a Target of the Beta-Catenin/LEF-1 Pathway. Proc. Natl. Acad. Sci. USA 1999, 96, 5522-5527. [CrossRef]

77. Angers, S.; Moon, R.T. Proximal Events in Wnt Signal Transduction. Nat. Rev. Mol. Cell Biol. 2009. [CrossRef] [PubMed]

78. Sharma, C.; Pradeep, A.; Wong, L.; Rana, A.; Rana, B. Peroxisome Proliferator-Activated Receptor Gamma Activation Can Regulate Beta-Catenin Levels via a Proteasome-Mediated and Adenomatous Polyposis Coli-Independent Pathway. J. Biol. Chem. 2004, 279, 35583-35594. [CrossRef] [PubMed]

79. Rosi, M.C.; Luccarini, I.; Grossi, C.; Fiorentini, A.; Spillantini, M.G.; Prisco, A.; Scali, C.; Gianfriddo, M.; Caricasole, A.; Terstappen, G.C.; et al. Increased Dickkopf-1 Expression in Transgenic Mouse Models of Neurodegenerative Disease. J. Neurochem. 2010, 112, 1539-1551. [CrossRef] [PubMed]

80. Clevers, H.; Nusse, R. Wnt/ $\beta$-Catenin Signaling and Disease. Cell 2012, 149, 1192-1205. [CrossRef] [PubMed]

81. Inestrosa, N.C.; Montecinos-Oliva, C.; Fuenzalida, M. Wnt Signaling: Role in Alzheimer Disease and Schizophrenia. J. Neuroimmune Pharmacol. Off. J. Soc. NeuroImmune Pharmacol. 2012, 7, 788-807. [CrossRef] [PubMed]

82. Vallée, A.; Lecarpentier, Y.; Guillevin, R.; Vallée, J.-N. Interactions between TGF-B1, Canonical WNT/ $\beta$-Catenin Pathway and PPAR $\gamma$ in Radiation-Induced Fibrosis. Oncotarget 2017, 8, 90579-90604. [CrossRef] [PubMed]

83. Vallée, A.; Lecarpentier, Y.; Vallée, J.-N. Hypothesis of Opposite Interplay Between the Canonical WNT/Beta-Catenin Pathway and PPAR Gamma in Primary Central Nervous System Lymphomas. Curr. Issues Mol. Biol. 2019, 31, 1-20. [CrossRef]

84. Aberle, H.; Bauer, A.; Stappert, J.; Kispert, A.; Kemler, R. $\beta$-Catenin Is a Target for the Ubiquitin-Proteasome Pathway. EMBO J. 1997, 16, 3797-3804. [CrossRef] [PubMed]

85. Wu, D.; Pan, W. GSK3: A Multifaceted Kinase in Wnt Signaling. Trends Biochem. Sci. 2010, 35, 161-168. [CrossRef] [PubMed]

86. Hur, E.-M.; Zhou, F.-Q. GSK3 Signalling in Neural Development. Nat. Rev. Neurosci. 2010, 11, 539-551. [CrossRef] [PubMed]

87. Ambacher, K.K.; Pitzul, K.B.; Karajgikar, M.; Hamilton, A.; Ferguson, S.S.; Cregan, S.P. The JNK- and AKT/GSK3 $\beta-$ Signaling Pathways Converge to Regulate Puma Induction and Neuronal Apoptosis Induced by Trophic Factor Deprivation. PLoS ONE 2012, 7, e46885. [CrossRef] [PubMed]

88. Orellana, A.M.M.; Vasconcelos, A.R.; Leite, J.A.; de Sá Lima, L.; Andreotti, D.Z.; Munhoz, C.D.; Kawamoto, E.M.; Scavone, C. Age-Related Neuroinflammation and Changes in AKT-GSK-3 $\beta$ and WNT/ $\beta$-CATENIN Signaling in Rat Hippocampus. Aging 2015, 7, 1094-1111. [CrossRef]

89. Inestrosa, N.C.; Arenas, E. Emerging Roles of Wnts in the Adult Nervous System. Nat. Rev. Neurosci. 2010, 11, 77-86. [CrossRef]

90. Berwick, D.C.; Harvey, K. LRRK2 Signaling Pathways: The Key to Unlocking Neurodegeneration? Trends Cell Biol. 2011, 21, 257-265. [CrossRef] 
91. L'episcopo, F.; Serapide, M.F.; Tirolo, C.; Testa, N.; Caniglia, S.; Morale, M.C.; Pluchino, S.; Marchetti, B. A Wnt1 Regulated Frizzled-1/ $\beta$-Catenin Signaling Pathway as a Candidate Regulatory Circuit Controlling Mesencephalic Dopaminergic NeuronAstrocyte Crosstalk: Therapeutical Relevance for Neuron Survival and Neuroprotection. Mol. Neurodegener. 2011, 6, 49. [CrossRef] [PubMed]

92. Häbig, K.; Walter, M.; Poths, S.; Riess, O.; Bonin, M. RNA Interference of LRRK2-Microarray Expression Analysis of a Parkinson's Disease Key Player. Neurogenetics 2008, 9, 83-94. [CrossRef] [PubMed]

93. Libro, R.; Bramanti, P.; Mazzon, E. The Role of the Wnt Canonical Signaling in Neurodegenerative Diseases. Life Sci. 2016, 158, 78-88. [CrossRef] [PubMed]

94. Zhou, T.; Zu, G.; Zhang, X.; Wang, X.; Li, S.; Gong, X.; Liang, Z.; Zhao, J. Neuroprotective Effects of Ginsenoside Rg1 through the Wnt/ $\beta$-Catenin Signaling Pathway in Both in Vivo and in Vitro Models of Parkinson's Disease. Neuropharmacology 2016, 101, 480-489. [CrossRef]

95. L'Episcopo, F.; Tirolo, C.; Testa, N.; Caniglia, S.; Morale, M.C.; Deleidi, M.; Serapide, M.F.; Pluchino, S.; Marchetti, B. Plasticity of Subventricular Zone Neuroprogenitors in MPTP (1-Methyl-4-Phenyl-1,2,3,6-Tetrahydropyridine) Mouse Model of Parkinson's Disease Involves Cross Talk between Inflammatory and Wnt/ $\beta$-Catenin Signaling Pathways: Functional Consequences for Neuroprotection and Repair. J. Neurosci. Off. J. Soc. Neurosci. 2012, 32, 2062-2085. [CrossRef]

96. Barthel, A.; Schmoll, D.; Unterman, T.G. FoxO Proteins in Insulin Action and Metabolism. Trends Endocrinol. Metab. TEM 2005, 16, 183-189. [CrossRef] [PubMed]

97. Almeida, M.; Ambrogini, E.; Han, L.; Manolagas, S.C.; Jilka, R.L. Increased Lipid Oxidation Causes Oxidative Stress, Increased Peroxisome Proliferator-Activated Receptor-Gamma Expression, and Diminished pro-Osteogenic Wnt Signaling in the Skeleton. J. Biol. Chem. 2009, 284, 27438-27448. [CrossRef]

98. Essers, M.A.G.; de Vries-Smits, L.M.M.; Barker, N.; Polderman, P.E.; Burgering, B.M.T.; Korswagen, H.C. Functional Interaction between Beta-Catenin and FOXO in Oxidative Stress Signaling. Science 2005, 308, 1181-1184. [CrossRef]

99. Hoogeboom, D.; Essers, M.A.G.; Polderman, P.E.; Voets, E.; Smits, L.M.M.; Burgering, B.M.T. Interaction of FOXO with BetaCatenin Inhibits Beta-Catenin/T Cell Factor Activity. J. Biol. Chem. 2008, 283, 9224-9230. [CrossRef]

100. Reif, K.; Burgering, B.M.; Cantrell, D.A. Phosphatidylinositol 3-Kinase Links the Interleukin-2 Receptor to Protein Kinase B and P70 S6 Kinase. J. Biol. Chem. 1997, 272, 14426-14433. [CrossRef]

101. Brunet, A.; Bonni, A.; Zigmond, M.J.; Lin, M.Z.; Juo, P.; Hu, L.S.; Anderson, M.J.; Arden, K.C.; Blenis, J.; Greenberg, M.E. Akt Promotes Cell Survival by Phosphorylating and Inhibiting a Forkhead Transcription Factor. Cell 1999, 96, 857-868. [CrossRef]

102. Stahl, M.; Dijkers, P.F.; Kops, G.J.P.L.; Lens, S.M.A.; Coffer, P.J.; Burgering, B.M.T.; Medema, R.H. The Forkhead Transcription Factor FoxO Regulates Transcription of P27Kip1 and Bim in Response to IL-2. J. Immunol. Baltim. Md 1950 2002, 168, 5024-5031. [CrossRef] [PubMed]

103. Schmidt, M.; Fernandez de Mattos, S.; van der Horst, A.; Klompmaker, R.; Kops, G.J.P.L.; Lam, E.W.-F.; Burgering, B.M.T.; Medema, R.H. Cell Cycle Inhibition by FoxO Forkhead Transcription Factors Involves Downregulation of Cyclin D. Mol. Cell. Biol. 2002, 22, 7842-7852. [CrossRef] [PubMed]

104. Fernández de Mattos, S.; Essafi, A.; Soeiro, I.; Pietersen, A.M.; Birkenkamp, K.U.; Edwards, C.S.; Martino, A.; Nelson, B.H.; Francis, J.M.; Jones, M.C.; et al. FoxO3a and BCR-ABL Regulate Cyclin D2 Transcription through a STAT5/BCL6-Dependent Mechanism. Mol. Cell. Biol. 2004, 24, 10058-10071. [CrossRef] [PubMed]

105. Manolopoulos, K.N.; Klotz, L.-O.; Korsten, P.; Bornstein, S.R.; Barthel, A. Linking Alzheimer's Disease to Insulin Resistance: The FoxO Response to Oxidative Stress. Mol. Psychiatry 2010, 15, 1046-1052. [CrossRef]

106. Shang, Y.C.; Chong, Z.Z.; Hou, J.; Maiese, K. Wnt1, FoxO3a, and NF-KappaB Oversee Microglial Integrity and Activation during Oxidant Stress. Cell. Signal. 2010, 22, 1317-1329. [CrossRef]

107. Halleskog, C.; Mulder, J.; Dahlström, J.; Mackie, K.; Hortobágyi, T.; Tanila, H.; Kumar Puli, L.; Färber, K.; Harkany, T.; Schulte, G. WNT Signaling in Activated Microglia Is Proinflammatory. Glia 2011, 59, 119-131. [CrossRef]

108. Ma, B.; Hottiger, M.O. Crosstalk between Wnt/ $\beta$-Catenin and NF- $\kappa$ B Signaling Pathway during Inflammation. Front. Immunol. 2016, 7, 378. [CrossRef]

109. Mitchell, S.; Vargas, J.; Hoffmann, A. Signaling via the NFкB System. Wiley Interdiscip. Rev. Syst. Biol. Med. 2016, 8, 227-241. [CrossRef]

110. Deng, J.; Miller, S.A.; Wang, H.-Y.; Xia, W.; Wen, Y.; Zhou, B.P.; Li, Y.; Lin, S.-Y.; Hung, M.-C. Beta-Catenin Interacts with and Inhibits NF-Kappa B in Human Colon and Breast Cancer. Cancer Cell 2002, 2, 323-334. [CrossRef]

111. Liu, J.; Liao, Y.; Ma, K.; Wang, Y.; Zhang, G.; Yang, R.; Deng, J. PI3K Is Required for the Physical Interaction and Functional Inhibition of NF- $\kappa$ B by $\beta$-Catenin in Colorectal Cancer Cells. Biochem. Biophys. Res. Commun. 2013, 434, 760-766. [CrossRef] [PubMed]

112. Martin, M.; Rehani, K.; Jope, R.S.; Michalek, S.M. Toll-like Receptor-Mediated Cytokine Production Is Differentially Regulated by Glycogen Synthase Kinase 3. Nat. Immunol. 2005, 6, 777-784. [CrossRef] [PubMed]

113. Manicassamy, S.; Reizis, B.; Ravindran, R.; Nakaya, H.; Salazar-Gonzalez, R.M.; Wang, Y.-C.; Pulendran, B. Activation of BetaCatenin in Dendritic Cells Regulates Immunity versus Tolerance in the Intestine. Science 2010, 329, 849-853. [CrossRef] [PubMed]

114. Cho, H.H.; Song, J.S.; Yu, J.M.; Yu, S.S.; Choi, S.J.; Kim, D.H.; Jung, J.S. Differential Effect of NF-KappaB Activity on BetaCatenin/Tcf Pathway in Various Cancer Cells. FEBS Lett. 2008, 582, 616-622. [CrossRef] [PubMed]

115. Fliniaux, I.; Mikkola, M.L.; Lefebvre, S.; Thesleff, I. Identification of Dkk4 as a Target of Eda-A1/Edar Pathway Reveals an Unexpected Role of Ectodysplasin as Inhibitor of Wnt Signalling in Ectodermal Placodes. Dev. Biol. 2008, 320, 60-71. [CrossRef] [PubMed] 
116. Hoeflich, K.P.; Luo, J.; Rubie, E.A.; Tsao, M.S.; Jin, O.; Woodgett, J.R. Requirement for Glycogen Synthase Kinase-3beta in Cell Survival and NF-KappaB Activation. Nature 2000, 406, 86-90. [CrossRef] [PubMed]

117. Beurel, E.; Michalek, S.M.; Jope, R.S. Innate and Adaptive Immune Responses Regulated by Glycogen Synthase Kinase-3 (GSK3). Trends Immunol. 2010, 31, 24-31. [CrossRef]

118. Lutgen, V.; Narasipura, S.D.; Sharma, A.; Min, S.; Al-Harthi, L. $\beta$-Catenin Signaling Positively Regulates Glutamate Uptake and Metabolism in Astrocytes. J. Neuroinflammation 2016, 13, 242. [CrossRef]

119. Narasipura, S.D.; Henderson, L.J.; Fu, S.W.; Chen, L.; Kashanchi, F.; Al-Harthi, L. Role of $\beta$-Catenin and TCF/LEF Family Members in Transcriptional Activity of HIV in Astrocytes. J. Virol. 2012, 86, 1911-1921. [CrossRef]

120. Lecarpentier, Y.; Schussler, O.; Hébert, J.-L.; Vallée, A. Molecular Mechanisms Underlying the Circadian Rhythm of Blood Pressure in Normotensive Subjects. Curr. Hypertens. Rep. 2020, 22, 50. [CrossRef]

121. Giese, K.P. GSK-3: A Key Player in Neurodegeneration and Memory. IUBMB Life 2009, 61, 516-521. [CrossRef] [PubMed]

122. Bauer, M.; Alda, M.; Priller, J.; Young, L.T.; International Group For The Study Of Lithium Treated Patients (IGSLI). Implications of the Neuroprotective Effects of Lithium for the Treatment of Bipolar and Neurodegenerative Disorders. Pharmacopsychiatry 2003, 36 (Suppl. 3), S250-S254. [CrossRef] [PubMed]

123. Rowe, M.K.; Chuang, D.-M. Lithium Neuroprotection: Molecular Mechanisms and Clinical Implications. Expert Rev. Mol. Med. 2004, 6, 1-18. [CrossRef] [PubMed]

124. Rowe, M.K.; Wiest, C.; Chuang, D.-M. GSK-3 Is a Viable Potential Target for Therapeutic Intervention in Bipolar Disorder. Neurosci. Biobehav. Rev. 2007, 31, 920-931. [CrossRef] [PubMed]

125. Alural, B.; Ozerdem, A.; Allmer, J.; Genc, K.; Genc, S. Lithium Protects against Paraquat Neurotoxicity by NRF2 Activation and MiR-34a Inhibition in SH-SY5Y Cells. Front. Cell. Neurosci. 2015, 9, 209. [CrossRef]

126. Beaulieu, J.-M.; Gainetdinov, R.R.; Caron, M.G. The Akt-GSK-3 Signaling Cascade in the Actions of Dopamine. Trends Pharmacol. Sci. 2007, 28, 166-172. [CrossRef]

127. Gould, T.D.; Chen, G.; Manji, H.K. In Vivo Evidence in the Brain for Lithium Inhibition of Glycogen Synthase Kinase-3. Neuropsychopharmacol. Off. Publ. Am. Coll. Neuropsychopharmacol. 2004, 29, 32-38. [CrossRef]

128. O’Brien, W.T.; Harper, A.D.; Jové, F.; Woodgett, J.R.; Maretto, S.; Piccolo, S.; Klein, P.S. Glycogen Synthase Kinase-3beta Haploinsufficiency Mimics the Behavioral and Molecular Effects of Lithium. J. Neurosci. Off. J. Soc. Neurosci. 2004, 24, 6791-6798. [CrossRef]

129. Jope, R.S.; Johnson, G.V.W. The Glamour and Gloom of Glycogen Synthase Kinase-3. Trends Biochem. Sci. 2004, 29, 95-102. [CrossRef]

130. Marmol, F. Lithium: Bipolar Disorder and Neurodegenerative Diseases Possible Cellular Mechanisms of the Therapeutic Effects of Lithium. Prog. Neuropsychopharmacol. Biol. Psychiatry 2008, 32, 1761-1771. [CrossRef]

131. Gould, T.D.; Einat, H.; O’Donnell, K.C.; Picchini, A.M.; Schloesser, R.J.; Manji, H.K. Beta-Catenin Overexpression in the Mouse Brain Phenocopies Lithium-Sensitive Behaviors. Neuropsychopharmacol. Off. Publ. Am. Coll. Neuropsychopharmacol. 2007, 32, 2173-2183. [CrossRef] [PubMed]

132. Gould, T.D.; O'Donnell, K.C.; Picchini, A.M.; Dow, E.R.; Chen, G.; Manji, H.K. Generation and Behavioral Characterization of Beta-Catenin Forebrain-Specific Conditional Knock-out Mice. Behav. Brain Res. 2008, 189, 117-125. [CrossRef] [PubMed]

133. Gould, T.D.; Quiroz, J.A.; Singh, J.; Zarate, C.A.; Manji, H.K. Emerging Experimental Therapeutics for Bipolar Disorder: Insights from the Molecular and Cellular Actions of Current Mood Stabilizers. Mol. Psychiatry 2004, 9, 734-755. [CrossRef]

134. Kim, Y.-H.; Rane, A.; Lussier, S.; Andersen, J.K. Lithium Protects against Oxidative Stress-Mediated Cell Death in $\alpha$-SynucleinOverexpressing in Vitro and in Vivo Models of Parkinson's Disease. J. Neurosci. Res. 2011, 89, 1666-1675. [CrossRef] [PubMed]

135. Lieu, C.A.; Dewey, C.M.; Chinta, S.J.; Rane, A.; Rajagopalan, S.; Batir, S.; Kim, Y.-H.; Andersen, J.K. Lithium Prevents Parkinsonian Behavioral and Striatal Phenotypes in an Aged Parkin Mutant Transgenic Mouse Model. Brain Res. 2014, 1591, 111-117. [CrossRef]

136. Hou, L.; Xiong, N.; Liu, L.; Huang, J.; Han, C.; Zhang, G.; Li, J.; Xu, X.; Lin, Z.; Wang, T. Lithium Protects Dopaminergic Cells from Rotenone Toxicity via Autophagy Enhancement. BMC Neurosci. 2015, 16, 82. [CrossRef]

137. Qi, L.; Tang, Y.; He, W.; Pan, H.; Jiang, W.; Wang, L.; Deng, W. Lithium Chloride Promotes Neuronal Differentiation of Rat Neural Stem Cells and Enhances Neural Regeneration in Parkinson's Disease Model. Cytotechnology 2017, 69, 277-287. [CrossRef]

138. Zhao, Q.; Liu, H.; Cheng, J.; Zhu, Y.; Xiao, Q.; Bai, Y.; Tao, J. Neuroprotective Effects of Lithium on a Chronic MPTP Mouse Model of Parkinson's Disease via Regulation of A-synuclein Methylation. Mol. Med. Rep. 2019, 19, 4989-4997. [CrossRef]

139. Wen, J.; Sawmiller, D.; Wheeldon, B.; Tan, J. A Review for Lithium: Pharmacokinetics, Drug Design, and Toxicity. CNS Neurol. Disord. Drug Targets 2019, 18, 769-778. [CrossRef]

140. Freland, L.; Beaulieu, J.-M. Inhibition of GSK3 by Lithium, from Single Molecules to Signaling Networks. Front. Mol. Neurosci. 2012, 5, 14. [CrossRef]

141. Noble, W.; Planel, E.; Zehr, C.; Olm, V.; Meyerson, J.; Suleman, F.; Gaynor, K.; Wang, L.; LaFrancois, J.; Feinstein, B.; et al. Inhibition of Glycogen Synthase Kinase-3 by Lithium Correlates with Reduced Tauopathy and Degeneration in Vivo. Proc. Natl. Acad. Sci. USA 2005, 102, 6990-6995. [CrossRef] [PubMed]

142. MacDonald, B.T.; Tamai, K.; He, X. Wnt/Beta-Catenin Signaling: Components, Mechanisms, and Diseases. Dev. Cell 2009, 17, 9-26. [CrossRef] [PubMed] 
143. Zhang, L.; Cen, L.; Qu, S.; Wei, L.; Mo, M.; Feng, J.; Sun, C.; Xiao, Y.; Luo, Q.; Li, S.; et al. Enhancing Beta-Catenin Activity via GSK3beta Inhibition Protects PC12 Cells against Rotenone Toxicity through Nurr1 Induction. PLoS ONE 2016, 11, e0152931. [CrossRef] [PubMed]

144. Aarsland, D.; Creese, B.; Politis, M.; Chaudhuri, K.R.; Ffytche, D.H.; Weintraub, D.; Ballard, C. Cognitive Decline in Parkinson Disease. Nat. Rev. Neurol. 2017, 13, 217-231. [CrossRef] [PubMed]

145. Su, Y.; Ryder, J.; Li, B.; Wu, X.; Fox, N.; Solenberg, P.; Brune, K.; Paul, S.; Zhou, Y.; Liu, F.; et al. Lithium, a Common Drug for Bipolar Disorder Treatment, Regulates Amyloid-Beta Precursor Protein Processing. Biochemistry 2004, 43, 6899-6908. [CrossRef]

146. Xilouri, M.; Brekk, O.R.; Stefanis, L. Autophagy and Alpha-Synuclein: Relevance to Parkinson's Disease and Related Synucleopathies. Mov. Disord. Off. J. Mov. Disord. Soc. 2016, 31, 178-192. [CrossRef]

147. Lipton, J.O.; Sahin, M. The Neurology of MTOR. Neuron 2014, 84, 275-291. [CrossRef]

148. Cuervo, A.M.; Stefanis, L.; Fredenburg, R.; Lansbury, P.T.; Sulzer, D. Impaired Degradation of Mutant Alpha-Synuclein by Chaperone-Mediated Autophagy. Science 2004, 305, 1292-1295. [CrossRef]

149. Motoi, Y.; Shimada, K.; Ishiguro, K.; Hattori, N. Lithium and Autophagy. ACS Chem. Neurosci. 2014, 5, 434-442. [CrossRef]

150. Sarkar, S.; Krishna, G.; Imarisio, S.; Saiki, S.; O’Kane, C.J.; Rubinsztein, D.C. A Rational Mechanism for Combination Treatment of Huntington's Disease Using Lithium and Rapamycin. Hum. Mol. Genet. 2008, 17, 170-178. [CrossRef]

151. Yang, Y.; Wang, H.; Wang, S.; Xu, M.; Liu, M.; Liao, M.; Frank, J.A.; Adhikari, S.; Bower, K.A.; Shi, X.; et al. GSK3 $\beta$ Signaling Is Involved in Ultraviolet B-Induced Activation of Autophagy in Epidermal Cells. Int. J. Oncol. 2012, 41, 1782-1788, [CrossRef] [PubMed]

152. Maeda, T.; Eisenberg, F. Purification, Structure, and Catalytic Properties of L-Myo-Inositol-1-Phosphate Synthase from Rat Testis. J. Biol. Chem. 1980, 255, 8458-8464. [CrossRef]

153. Sarkar, S.; Floto, R.A.; Berger, Z.; Imarisio, S.; Cordenier, A.; Pasco, M.; Cook, L.J.; Rubinsztein, D.C. Lithium Induces Autophagy by Inhibiting Inositol Monophosphatase. J. Cell Biol. 2005, 170, 1101-1111. [CrossRef] [PubMed]

154. Criollo, A.; Vicencio, J.M.; Tasdemir, E.; Maiuri, M.C.; Lavandero, S.; Kroemer, G. The Inositol Trisphosphate Receptor in the Control of Autophagy. Autophagy 2007, 3, 350-353. [CrossRef]

155. Cannon, J.R.; Tapias, V.; Na, H.M.; Honick, A.S.; Drolet, R.E.; Greenamyre, J.T. A Highly Reproducible Rotenone Model of Parkinson's Disease. Neurobiol. Dis. 2009, 34, 279-290. [CrossRef]

156. Lazzara, C.A.; Riley, R.R.; Rane, A.; Andersen, J.K.; Kim, Y.-H. The Combination of Lithium and L-Dopa/Carbidopa Reduces MPTP-Induced Abnormal Involuntary Movements (AIMs) via Calpain-1 Inhibition in a Mouse Model: Relevance for Parkinson's Disease Therapy. Brain Res. 2015, 1622, 127-136. [CrossRef]

157. Xiong, N.; Jia, M.; Chen, C.; Xiong, J.; Zhang, Z.; Huang, J.; Hou, L.; Yang, H.; Cao, X.; Liang, Z.; et al. Potential Autophagy Enhancers Attenuate Rotenone-Induced Toxicity in SH-SY5Y. Neuroscience 2011, 199, 292-302. [CrossRef]

158. Li, X.; Chen, X.; Zhao, K.; Bai, L.; Zhang, H.; Zhou, X. Therapeutic Effects of Valproate Combined with Lithium Carbonate on MPTP-Induced Parkinsonism in Mice: Possible Mediation through Enhanced Autophagy. Int. J. Neurosci. 2013, 123, 73-79. [CrossRef]

159. Ferrucci, M.; Pasquali, L.; Ruggieri, S.; Paparelli, A.; Fornai, F. Alpha-Synuclein and Autophagy as Common Steps in Neurodegeneration. Parkinsonism Relat. Disord. 2008, 14 (Suppl. 2), S180-S184. [CrossRef]

160. Mao, Z.; Liu, L.; Zhang, R.; Li, X. Lithium Reduces FoxO3a Transcriptional Activity by Decreasing Its Intracellular Content. Biol. Psychiatry 2007, 62, 1423-1430. [CrossRef]

161. Shao, L.; Young, L.T.; Wang, J.-F. Chronic Treatment with Mood Stabilizers Lithium and Valproate Prevents Excitotoxicity by Inhibiting Oxidative Stress in Rat Cerebral Cortical Cells. Biol. Psychiatry 2005, 58, 879-884. [CrossRef] [PubMed]

162. De Vasconcellos, A.P.S.; Nieto, F.B.; Crema, L.M.; Diehl, L.A.; de Almeida, L.M.; Prediger, M.E.; da Rocha, E.R.; Dalmaz, C. Chronic Lithium Treatment Has Antioxidant Properties but Does Not Prevent Oxidative Damage Induced by Chronic Variate Stress. Neurochem. Res. 2006, 31, 1141-1151. [CrossRef] [PubMed]

163. Cui, J.; Shao, L.; Young, L.T.; Wang, J.-F. Role of Glutathione in Neuroprotective Effects of Mood Stabilizing Drugs Lithium and Valproate. Neuroscience 2007, 144, 1447-1453. [CrossRef] [PubMed]

164. Frey, B.N.; Andreazza, A.C.; Kunz, M.; Gomes, F.A.; Quevedo, J.; Salvador, M.; Gonçalves, C.A.; Kapczinski, F. Increased Oxidative Stress and DNA Damage in Bipolar Disorder: A Twin-Case Report. Prog. Neuropsychopharmacol. Biol. Psychiatry 2007, 31, 283-285. [CrossRef] [PubMed]

165. Machado-Vieira, R.; Andreazza, A.C.; Viale, C.I.; Zanatto, V.; Cereser, V.; da Silva Vargas, R.; Kapczinski, F.; Portela, L.V.; Souza, D.O.; Salvador, M.; et al. Oxidative Stress Parameters in Unmedicated and Treated Bipolar Subjects during Initial Manic Episode: A Possible Role for Lithium Antioxidant Effects. Neurosci. Lett. 2007, 421, 33-36. [CrossRef]

166. Rodríguez de la Concepción, M.L.; Yubero, P.; Iglesias, R.; Giralt, M.; Villarroya, F. Lithium Inhibits Brown Adipocyte Differentiation. FEBS Lett. 2005, 579, 1670-1674. [CrossRef]

167. Lee, C.-H.; Olson, P.; Evans, R.M. Minireview: Lipid Metabolism, Metabolic Diseases, and Peroxisome Proliferator-Activated Receptors. Endocrinology 2003, 144, 2201-2207. [CrossRef]

168. Marx, N.; Duez, H.; Fruchart, J.-C.; Staels, B. Peroxisome Proliferator-Activated Receptors and Atherogenesis: Regulators of Gene Expression in Vascular Cells. Circ. Res. 2004, 94, 1168-1178. [CrossRef]

169. Cunard, R.; Ricote, M.; DiCampli, D.; Archer, D.C.; Kahn, D.A.; Glass, C.K.; Kelly, C.J. Regulation of Cytokine Expression by Ligands of Peroxisome Proliferator Activated Receptors. J. Immunol. Baltim. Md 1950 2002, 168, 2795-2802. [CrossRef] 
170. Ricote, M.; Li, A.C.; Willson, T.M.; Kelly, C.J.; Glass, C.K. The Peroxisome Proliferator-Activated Receptor-Gamma Is a Negative Regulator of Macrophage Activation. Nature 1998, 391, 79-82. [CrossRef]

171. Giannini, S.; Serio, M.; Galli, A. Pleiotropic Effects of Thiazolidinediones: Taking a Look beyond Antidiabetic Activity. J. Endocrinol. Invest. 2004, 27, 982-991. [CrossRef] [PubMed]

172. Vallée, A.; Lecarpentier, Y. Crosstalk Between Peroxisome Proliferator-Activated Receptor Gamma and the Canonical WNT/ $\beta$-Catenin Pathway in Chronic Inflammation and Oxidative Stress During Carcinogenesis. Front. Immunol. 2018, 9, 745. [CrossRef] [PubMed]

173. Vallée, A.; Vallée, J.-N.; Lecarpentier, Y. PPAR $\gamma$ Agonists: Potential Treatment for Autism Spectrum Disorder by Inhibiting the Canonical WNT/ $\beta$-Catenin Pathway. Mol. Psychiatry 2018. [CrossRef] [PubMed]

174. Vallée, A.; Lecarpentier, Y.; Guillevin, R.; Vallée, J.-N. Thermodynamics in Gliomas: Interactions between the Canonical WNT/Beta-Catenin Pathway and PPAR Gamma. Front. Physiol. 2017, 8, 352. [CrossRef] [PubMed]

175. Vallée, A.; Lecarpentier, Y.; Guillevin, R.; Vallée, J.-N. Demyelination in Multiple Sclerosis: Reprogramming Energy Metabolism and Potential PPAR $\gamma$ Agonist Treatment Approaches. Int. J. Mol. Sci. 2018, 19, 1212. [CrossRef]

176. Park, K.S.; Lee, R.D.; Kang, S.-K.; Han, S.Y.; Park, K.L.; Yang, K.H.; Song, Y.S.; Park, H.J.; Lee, Y.M.; Yun, Y.P.; et al. Neuronal Differentiation of Embryonic Midbrain Cells by Upregulation of Peroxisome Proliferator-Activated Receptor-Gamma via the JNK-Dependent Pathway. Exp. Cell Res. 2004, 297, 424-433. [CrossRef]

177. Vallée, A.; Vallée, J.-N. Warburg Effect Hypothesis in Autism Spectrum Disorders. Mol. Brain 2018, 11, 1. [CrossRef] [PubMed]

178. Grimes, C.A.; Jope, R.S. The Multifaceted Roles of Glycogen Synthase Kinase 3beta in Cellular Signaling. Prog. Neurobiol. 2001, 65, 391-426. [CrossRef]

179. Jeon, M.; Rahman, N.; Kim, Y.-S. Wnt/ $\beta$-Catenin Signaling Plays a Distinct Role in Methyl Gallate-Mediated Inhibition of Adipogenesis. Biochem. Biophys. Res. Commun. 2016, 479, 22-27. [CrossRef]

180. Gustafson, B.; Eliasson, B.; Smith, U. Thiazolidinediones Increase the Wingless-Type MMTV Integration Site Family (WNT) Inhibitor Dickkopf-1 in Adipocytes: A Link with Osteogenesis. Diabetologia 2010, 53, 536-540. [CrossRef]

181. Basu, A.; Haldar, S. The Relationship between BcI2, Bax and P53: Consequences for Cell Cycle Progression and Cell Death. Mol. Hum. Reprod. 1998, 4, 1099-1109. [CrossRef] [PubMed]

182. Chen, G.; Rajkowska, G.; Du, F.; Seraji-Bozorgzad, N.; Manji, H.K. Enhancement of Hippocampal Neurogenesis by Lithium. J. Neurochem. 2000, 75, 1729-1734. [CrossRef] [PubMed]

183. Youdim, M.B.H.; Arraf, Z. Prevention of MPTP (N-Methyl-4-Phenyl-1,2,3,6-Tetrahydropyridine) Dopaminergic Neurotoxicity in Mice by Chronic Lithium: Involvements of Bcl-2 and Bax. Neuropharmacology 2004, 46, 1130-1140. [CrossRef] [PubMed]

184. Ruvolo, P.P.; Deng, X.; May, W.S. Phosphorylation of Bcl2 and Regulation of Apoptosis. Leukemia 2001, 15, 515-522. [CrossRef] [PubMed]

185. Chen, C.-L.; Lin, C.-F.; Chiang, C.-W.; Jan, M.-S.; Lin, Y.-S. Lithium Inhibits Ceramide- and Etoposide-Induced Protein Phosphatase 2A Methylation, Bcl-2 Dephosphorylation, Caspase-2 Activation, and Apoptosis. Mol. Pharmacol. 2006, 70, 510-517. [CrossRef]

186. Abousaab, A.; Lang, F. Up-Regulation of Excitatory Amino Acid Transporters EAAT3 and EAAT4 by Lithium Sensitive Glycogen Synthase Kinase GSK3B. Cell. Physiol. Biochem. Int. J. Exp. Cell. Physiol. Biochem. Pharmacol. 2016, 40, 1252-1260. [CrossRef]

187. Yoshii, A.; Constantine-Paton, M. Postsynaptic BDNF-TrkB Signaling in Synapse Maturation, Plasticity, and Disease. Dev. Neurobiol. 2010, 70, 304-322. [CrossRef]

188. Scheuing, L.; Chiu, C.-T.; Liao, H.-M.; Chuang, D.-M. Antidepressant Mechanism of Ketamine: Perspective from Preclinical Studies. Front. Neurosci. 2015, 9, 249. [CrossRef]

189. Chiu, C.-T.; Scheuing, L.; Liu, G.; Liao, H.-M.; Linares, G.R.; Lin, D.; Chuang, D.-M. The Mood Stabilizer Lithium Potentiates the Antidepressant-like Effects and Ameliorates Oxidative Stress Induced by Acute Ketamine in a Mouse Model of Stress. Int. J. Neuropsychopharmacol. 2014, 18. [CrossRef]

190. Chiu, C.-T.; Chuang, D.-M. Molecular Actions and Therapeutic Potential of Lithium in Preclinical and Clinical Studies of CNS Disorders. Pharmacol. Ther. 2010, 128, 281-304. [CrossRef]

191. Verhoef, L.G.G.C.; Lindsten, K.; Masucci, M.G.; Dantuma, N.P. Aggregate Formation Inhibits Proteasomal Degradation of Polyglutamine Proteins. Hum. Mol. Genet. 2002, 11, 2689-2700. [CrossRef] [PubMed]

192. Harris, H.; Rubinsztein, D.C. Control of Autophagy as a Therapy for Neurodegenerative Disease. Nat. Rev. Neurol. 2011, 8 , 108-117. [CrossRef] [PubMed]

193. Lorzadeh, S.; Kohan, L.; Ghavami, S.; Azarpira, N. Autophagy and the Wnt Signaling Pathway: A Focus on Wnt/ $\beta-C a t e n i n$ Signaling. Biochim. Biophys. Acta Mol. Cell Res. 2020, 1868, 118926. [CrossRef] [PubMed] 